\title{
A RECONNAISSANCE SURVEY ON THE QUATERNARY HISTORY OF ST. PIERRE ET MIQUELON, FRANCE
}

\author{
C.M. TUCKER
}

Engineering and Terrain Geology Section, Ontario Geological Survey

77 Grenville Street, Toront, Ontario, CANADA M5S 1B3

\section{INTRODUCTION}

The purpose of this paper is to document several observations on the Quaternary history of the islands of St. Pierre et Miquelon which were determined on visits during 1976 and 1977. The results form part of a more complete study on Quaternary events along the southeastern coast of Newfoundland (Tucker 1979, Tucker and McCann, in press). Because the islands of St. Pierre et Miquelon are close to the Burin Peninsula of Newfoundland, the main portion of the research area, and situated well south of the late-Wisconsinan ice margin proposed by Grant (1977), it was considered essential that they be included in the total study. This presented a logistics problem in that access to more interesting parts of the archipelago is difficult. Due to time constraints, only a brief reconnaissance was carried out. Nevertheless, several important new insights on the Quaternary record were gained and are discussed below.

\section{LOCATION AND PHYSIOGRAPHY}

The French islands are situated at the entrance of Fortune Bay approximately $25 \mathrm{~km}$ southwest of the Burin Peninsula (Fig. 1), and are contained within the area defined by $46^{\circ} 45^{\prime}$ to $47^{\circ} 10^{\prime} \mathrm{N}$ latitude, and $56^{\circ} 05^{\prime}$ to $56^{\circ} 25^{\prime} \mathrm{W}$ longitude. The territory consists of three principal islands, St. Pierre, Langlade, and Miquelon, as well as a number of smaller islands located northeast of St. Pierre. Langlade and Miquelon although considered separate islands, have been connected by an isthmus of sand dunes some $12 \mathrm{~km}$ in length since the end of the eighteenth century (Aubert de la Rug, 1951).

The physiography of the $240 \mathrm{~km}$ territory is similar to that found on the lower Burin Peninsula of Newfoundland in that its surface of 120 to $150 \mathrm{~m}$ a.s.l. rises gently to the northeast and is broken only by occasional hills of 150 to $200 \mathrm{~m}$ in elevation. The highest, Morne de la Grande Montagne, is located on Miquelon, and extends $240 \mathrm{~m}$ a.s.1. Surficial cover of the islands is variable. For the most part, St. Pierre is drift-free while Langlade and Miquelon have more extensive thicknesses of surficial material in their uplands. It is heavily masked by organic cover which makes it difficult to interpret depths precisely. Weathered, tor-like rock knobs are more common on Miquelon, which indicates that deposits are thinner than on Langlade. Below $20 \mathrm{~m}$, surficial material is thicker and has a subdued, rolling to planar appearance. This is especially so along the south coast of St. Pierre, the perimeter of Miquelon, and along the west and south coast of Langlade.

Drainage is poorly developed on the islands. Ponds are contained in shallow bedrock depressions or troughs from which streams flow from the local heights of land to more level ground. Exceptions occur along the west and south coast of Langlade where streams such as Deuxième Ruisseau Maquine are incised to a depth of 50 to $60 \mathrm{~m}$ in the $150 \mathrm{~m}$ a.s.1. plateau. At a point about $20 \mathrm{~m}$ a.s.1. the streams have developed a well entrenched pattern of meanders and flow through surficial cover to the coast. A similar pattern occurs on the eastern and northeastern coast of Miquelon, though here, the meanders extend further in elevation because of greater thicknesses of unconsolidated material. Features of coastal submergence are ubiquitous with major barrier islands, beaches and lagoons occurring around the perimeter of Miquelon and along the south coast of St. Pierre. The town of Miquelon is built on a raised, cobble-gravel foreland that although greater than $1.2 \mathrm{~km}$ in east-west extent, is less than $10 \mathrm{~m} \mathrm{a.s.1.} \mathrm{in} \mathrm{elevation.}$

\section{BEDROCK GEOLOGY}

The bedrock geology has been interpreted mainly through the work of Aubert de la Rue (1932, 1946, 1951). More recently, it has been generalized by Williams (1978). The oldest units are the Precambrian, sedimentary volcanic rocks found on St. Pierre and Miquelon. These are correlative with the northeasterly trending zone of acidicbasic volcanic rocks, schistose, prophyritic felsite and tuff located on the southewestern coast of the Burin Peninsula. Le Cap, north of Miquelon consists of Precambrian metamorphics with zones of quartzite, gneiss, paragneiss and granitization. The bedrock on Langlade is Cambrian to Middle ordovician in age and reveals suites of rock similar to those in the Dantzic Cove-Fortune area of the Burin Peninsula. These marine shelf sediments contain northeasterly trending belts of red to grey sandstone and siltstone, black slate, quartzites and minor limestone. Minor plugs of intrusive rhyolites are present at the northeastern corner of Langlade.

\section{PREVIOUS RESEARCH}

Information on Quaternary deposits is contained in the various reports of Aubert de la Rue. He contended (1932) that the islands were completely glaciated by ice originating in Newfoundland. This was indicated by the presence of foreign, coarsegrained erratics lying on quartzite at Belle Rivière, Langlade, as well as on the lowland north of Miquelon. He further suggested that a terrestrial link with Newfoundland occurred during this stage. Ground moraine is described as being $3.5 \mathrm{~m}$ thick, except at Petit Barachois and on the lower east coast of Miquelon where deposits are greater than $30 \mathrm{~m}$ thick. Small frontal moraines, a result of local cirque glaciers, were noted at Miquelon, though their exact locations were not described. Aubert de la Rue mentioned the occurrence of micro-indicators of 


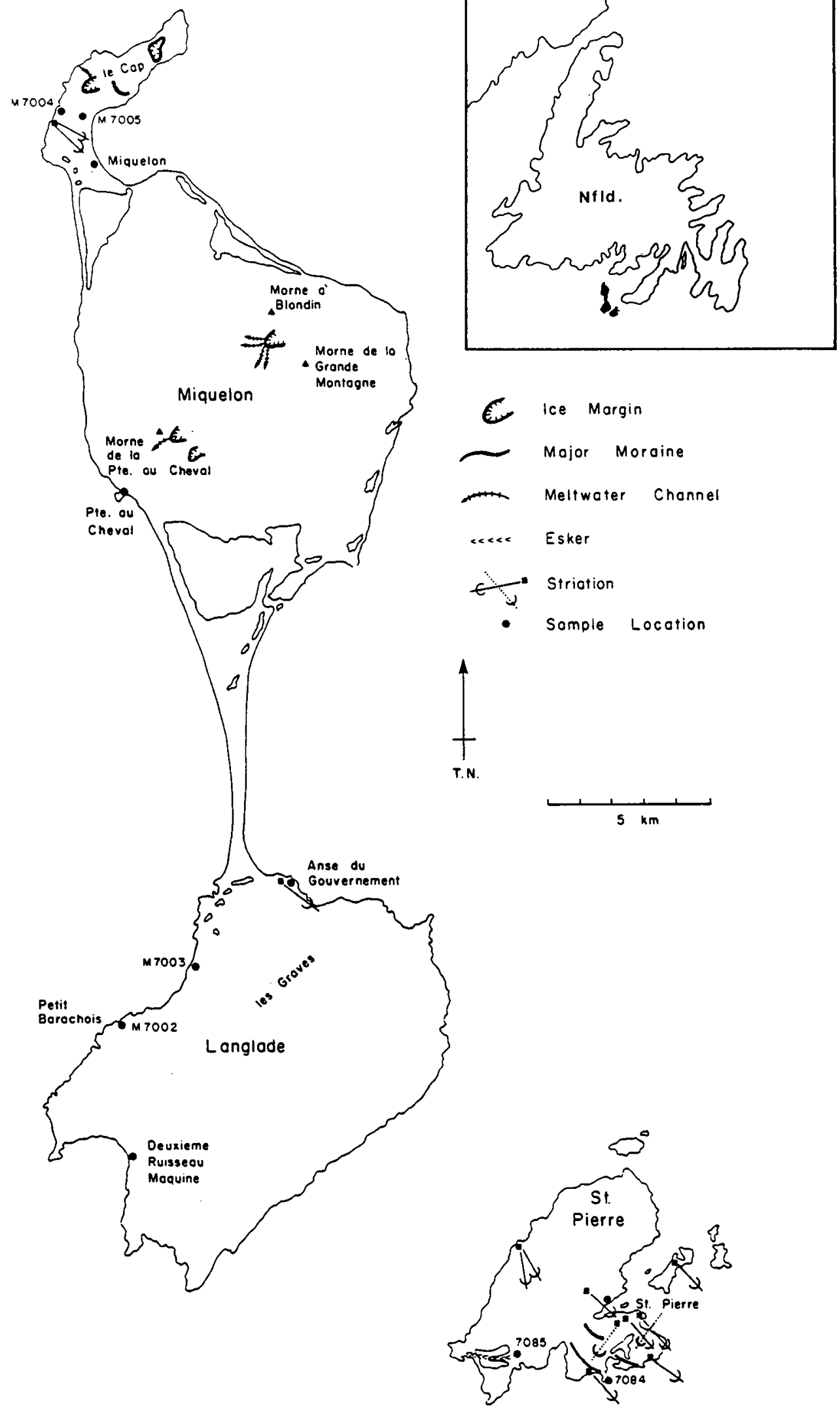

FIG. 1 Location map and glacial features. 
ice movement such as rôches moutonnêes, glacial polish, and striae oriented at $110^{\circ}$ to $150^{\circ}$ azimuth located northeast of the town of St. Pierre and near Pointe au Cheval, Miquelon. Periglacial features such as solifluction lobes, talus and felsenmeer are also described at various locations, as are aeolian ventifacts and grass covered dunes at Petit Barachois which are said to overlie till. He determined the source of the dune material to be postglacial marine sands and gravels, so called because of the lack of overlying erratics. Although he was aware of the 15 to $20 \mathrm{~m} \mathrm{a.s.1.} \mathrm{raised}$ terrace remnants at the head of Fortune Bay, Newfoundland, he did not consider that the French territory had been affected by isostatic uplift since the end of the last glaciation; rather, that bay mouth bars and tombolos indicate that submergence is occurring.

\section{GLACIAL PATTERNS}

The St. Pierre et Miquelon archipelago could most aptly be described as having a homogenous surface morphology with a distinct lack of glacial features indicating directions of former ice movement. There are, however, several limited patterns that were developed and are detailed in Figure 1. Along the lower south coast of $\mathrm{st.}$ Pierre there are two poorly preserved recessional moraine remnants that are oriented northwestsoutheast, and are open towards the northeast. They are less than $15 \mathrm{~m}$ in height, highly dissected, and rock-cored. At Anse de Savoyard, $2.5 \mathrm{~km}$ to the west, an esker that is oriented approximately westnorthwest, crosses the harbour and extends below sea level. This suggests that the last glacial, hydrological gradient was to the west or northwest. Above $25 \mathrm{~m}$ a.s.1., st. Pierre is essentially free of either drift or glacial features.

Both Langlade and Miquelon have significantly different surface morphologies to that of St. Pierre. The valleys along the steep southern and eastern coasts of Langlade contain thick sequences of surficial material that have been cut by fluvial action. As well, coastal sections contain as much as $50 \mathrm{~m}$ of unconsolidated deposits that have been well exposed because of coastal storms and marine erosion. The highland areas are drift covered, but generally, bedrock is close to the surface, Air-photo analysis reveals no features that might be termed ice marginal, and drainage is well integrated with the present landscape. Near the northwestern corner of the island, several fossil drainage channels are evident, but these are considered to represent normal incision of a fluvial system rather than meltwater flow.

The surficial cover of Miquelon is not as subdued as that on Langlade. The highlands have a more rugged appearance and till is not as thick either in the uplands or in coastal sections. Interestingly, the central uplands contain several arcuate, relict ice margins that are open to the northeast. They are located at 120 to $130 \mathrm{~m}$ between Morne à Blondin and Morne de la Grande Montagne in the east, and Morne de la Pointe au Cheval in the southwest. All three ice margins are poorly preserved, and were identified mainly because of the presence of meltwater channels that radiate away to the southwest. On le Cap of Miquelon, there are three former ice marginal positions. The most prominent is situated just south of Butte au Berry and consists of a small cirque with a recessional moraine on its southwest slope. In all cases, meltwater flow from these positions was to the west and southwest.

Because field work on St. Pierre et Miquelon was limited, the pattern of striae that was discovered is less than ideal, however, two trends developed. The most well developed mirror ice flow from the south coast of Newfoundland and are oriented $135^{\circ}$ to $160^{\circ}$. The younger were measured only southeast of the town of St. Pierre, but significantly, are directed $220^{\circ}$ which is perpendicular to the long axis of the recessional moraines mapped along the south coast of the island.

\section{GLACIAL DEPOSITS AND STRATIGRAPHY}

Surficial material was collected on St. Pierre for textural and provenance analyses. There were several reasons for this. It was hoped that a more precise insight could be gained on the distance and directions of glacial transport. Also, it appeared from air-photo analysis that much of the lowland had been inundated by the sea at some point, and again, this needed clarification.

Sample 7084 was retrieved from a $3-m$ coastal section located at Tête du Petit Havre. The material is a washed, medium brown, sandy till with angular to sub-angular clasts averaging 8 to $10 \mathrm{~cm}$ in diameter. More than 80 per cent of the clasts are local Precambrian rhyolites, and rhyolotic breccias and tuffs. Transport from Miquelon is indicated by the presence of Paleozoic phyllites and Cambrian quartzites. No distinct transport from Newfoundland was readily discernible from the analysis. The texture of the sample is very sandy, with a mean grain size of $0.70 \phi$, and very poor sorting. The mean grain-size parameters compare favorably with those of the upper tills of the St. Lawrence plateau described in Tucker (1979). A distinct lack of matrix in the upper half metre of the section would suggest that the material had been reworked to some extent by marine action.

Iithologic sources were also determined for clasts contained in the esker at Anse de Savoyard (Iocation 7085). Although the majority were locally derived from rhyolites, agglomerates, rhyolitic tuffs and breccias as well as basalt, 10 per cent had sources on langlade. The possibility exists that some of this material may have been from Newfoundland especially when considered in light of the onshore striae near St. Pierre, although, with local sources so predominant, proving a Newfoundland origin becomes difficult.

Based on a preliminary interpretation of air photos, a foot traverse was carried out from Miquelon to Petit Barachois, which is located about mid-point on the western coast of Langlade. It was felt that even a cursory appraisal of the nearly $40 \mathrm{~m}$ of surficial material at this site would significantly aid the interpretation of Quaternary events on the southeastern coast of Newfoundland. Aubert de la Rue (1946) described 


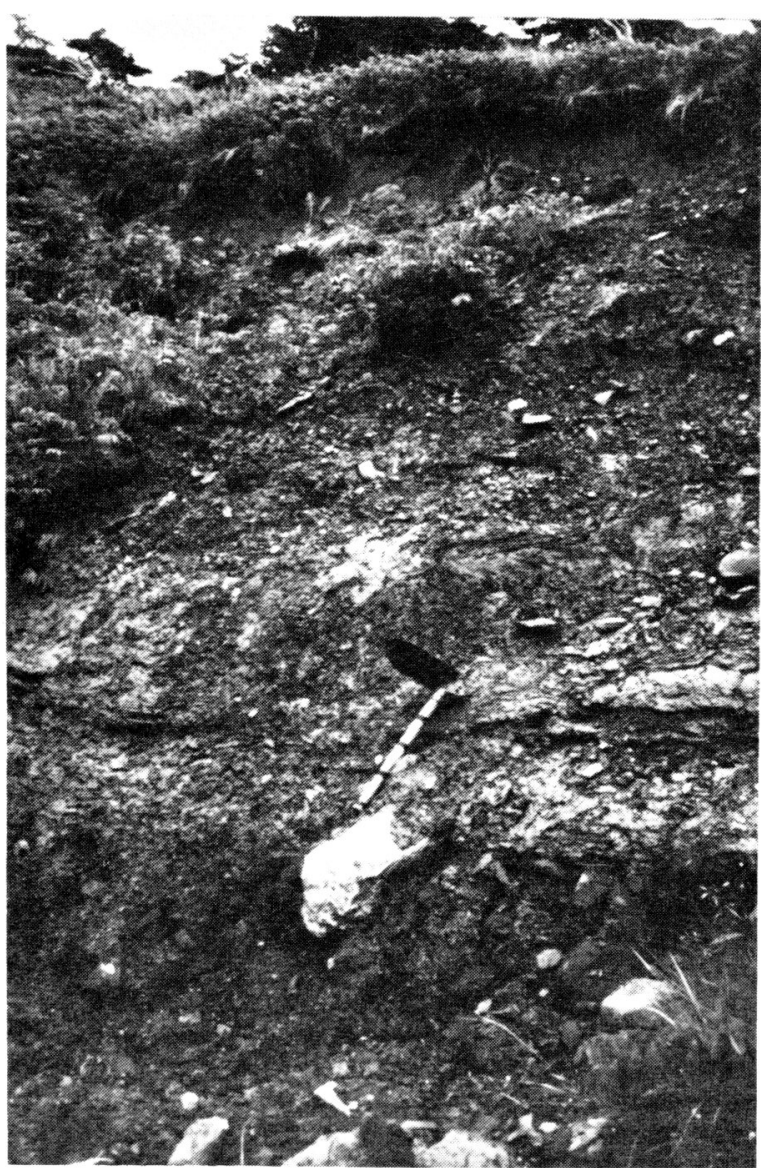

FIG. 2 Lower portion of Petit Barachois, Langlade section. Spade indicates location of sample M7002B.

the west coast of Langlade as containing till derived from the Newfoundland ice sheet overlain by as much as $7 \mathrm{~m}$ of aeolian sand. Between the two units, he reported finding roots which he interpreted as being postglacial in age. Unfortunately, they were not rediscovered during the present writer's brief visit to Langlade in 1977.

The section is located on the coast $0.9 \mathrm{~km}$ southwest of Petit Barachois and in detail (Fig. $2)$, the lower portion reveals $2.4 \mathrm{~m}$ of red sandstone which is overlain by $18 \mathrm{~m}$ of compact, grey-pink marine silt and sand. The unit contains rounded to subrounded cobbles and pebbles many of which, though not all, are striated. These are considered to have been deposited by ice rafting from Newfoundland sources. Provenance of the clasts (Sample M7002A) indicates that although most is local, Cambrian and Paleozoic material, 4 percent is coarse grained, Devonian granite that probably originated in the Cape la Hune-Rencontre West area of Newfoundland (see Williams, 1971). At $2.6 \mathrm{~m}$ and $16.6 \mathrm{~m}$, two distinct, horizontal beds of grey, laminated marine silt were noted. The first is $30 \mathrm{~cm}$ thick, and the second was measured as being $1.4 \mathrm{~m}$ in depth. Significantly, both contain benthonic marine foraminifera of species similar in age and paleoenvironment to those occurring at Dantzic Cove on the Burin Peninsula (Table 1). Vilks (pers. comm.) considered that the foraminifera indicate a paleoenvironment of inner shelf, marginal marine conditions, possibly an estuarine bay with a salt wedge. They are also similar to a suite at Salmon River, Nova Scotia, dated at 38,600 B.P. (Nielsen 1974, Wagner 1977) and, hence, are thought to be an indicator of mid-Wisconsinan marine overlap.

At several points on the surface of this lower marine unit, small concretions were discovered that have been termed marlekor or imatra stones by Pettijohn (1975). The examples noted have irregular central columns with round nodules up to $3 \mathrm{~cm}$ in diameter. In addition, simpler, discoid forms of varying dimensions were found at the site. Marlekor were also noted on Langlade by Aubert de la Rue (1946) who considered the "pseudoconcrêtions argilosableuses" to be a post glacial form. He suggested that they originated at the interface of $7 \mathrm{~m}$ of dune sands overlying $25 \mathrm{~m}$ of till, when calcite-rich groundwater reached a subaerial environment. The present author disagrees with Aubert de la Rue on both interpretations. The lower unit is not considered to be till despite the foreign clasts, and the concretions are not a subaerial form. Because specimens were dug from within, as well as being collected on the surface of the unit, the origin described by Tarr (1935) for similar, glaciolacustrine features is thought to be more likely. He believed their source to be calcite and $\mathrm{Al}-\mathrm{Fe}-\mathrm{Mn}$ compounds brought into the submarine environment from glacier-fed waters both as clastic grains and in soluble form. These were deposited mechanically, chemically and organically, chiefly in the silts. The cold, $\mathrm{CO}_{2}$-rich waters that were buried with the silts gradually dissolved the deposited particles. Subsequently, due to climatic changes, these waters became warmer, which caused a loss of their $\mathrm{CO}_{2}$ content, and deposition of the various compounds with changes in water $\mathrm{pH}$. Later, subaerial groundwater flow added to the forms, with the greatest increase in material occurring on their up-surface sides. This genesis adds credence to calling the lower unit marine, especially because silty tills known in the local area are so lacking in calcite and $\mathrm{Al}-\mathrm{Fe}-\mathrm{Mn} \mathrm{com}-$ pounds as to be unsuitable as a direct source. In fact, the Langlade marlekor contain so little calcite that no attempt could be made to date them by isotopic methods.

Above the $18 \mathrm{~m}$ of grey-pink marine silt and sand, there is a distinct facies change to very loose, planar cross-bedded, coarse, quartzose sand and cobble gravel. At Petit Barachois, this unit extends to a height of $35.2 \mathrm{~m}$ of which the upper $10 \mathrm{~m}$ or so has been dissected by fluvial action and reworked by aeolian processes. Similar stratigraphy exists in a river cut near the mouth of Ruisseau Debons, $1.8 \mathrm{~km}$ northeast of Petit Barachois (Location M7003). Here, 11.5 m of contorted marine silt, sand and ice-rafted debris containing foreign clasts are overlain by quartz-rich aeolian sands derived from the marine sands and gravels. Farther north, this material has supplied much of the sands which constitute the isthmus between Langlade and Miquelon.

Despite the report of plant roots beneath the aeolian material (Aubert de la Rue 1946), the whole sequence of material along the west coast of 
TABLE 1

Foraminifera Suites Burin Peninsula, Newfoundland - St. Pierre et Miquelon (G. Vilks, pers. comm.)

SAMPLE NUMBER

SPECIES

\begin{tabular}{|c|c|c|c|}
\hline 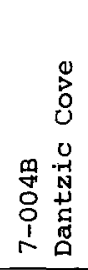 & 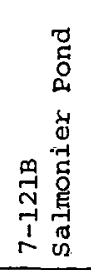 & 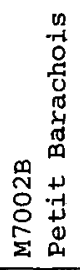 & 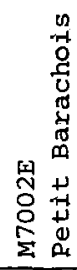 \\
\hline
\end{tabular}

\begin{tabular}{|c|c|c|c|c|c|c|}
\hline Astrononion galzowayi & $\mathbf{x}$ & $\mathbf{x}$ & $\mathrm{x}$ & $\mathrm{x}$ & $\mathrm{x}$ & arctic, cold water \\
\hline Bolivina pseudopunctata & & & & $\mathbf{x}$ & $\mathbf{x}$ & silty, nearshore abyssal \\
\hline Bolivina pseudoplicata & & $\mathbf{x}$ & & & $\mathrm{x}$ & open water \\
\hline Bolivina subaenariensis & & & & $\mathbf{x}$ & $\mathrm{x}$ & open water \\
\hline Bolivina spatulata & $\mathrm{x}$ & $\mathbf{x}$ & & & $\mathrm{x}$ & open water \\
\hline Buccelza frigida & $x$ & & $\mathbf{x}$ & & & nearshore, open bay \\
\hline Bulimina sp. & $x$ & & & & & ancient, nearshore - abyssal \\
\hline Bulimina aculeata & & & & $\mathrm{x}$ & $\mathrm{x}$ & ancient, nearshore - aybssal \\
\hline Bulimina cf. gibba & & & $\mathrm{x}$ & & & ancient, nearshore - abyssal \\
\hline Cassidelza complanata & & $\mathrm{x}$ & & $x$ & & deep water, outer shelf \\
\hline Cibicides concentricus & & & & & $\mathbf{x}$ & sandy nearshore - abyssal \\
\hline Cibicides lobatulus & $\mathbf{x}$ & $\mathbf{x}$ & $\mathrm{x}$ & $x$ & $\mathrm{x}$ & sandy nearshore \\
\hline Elphidium barletti & & $\mathbf{x}$ & & & & low saline, shallow water \\
\hline Elphidium clavatron & $\mathrm{x}$ & $\mathrm{x}$ & $\mathbf{x}$ & $\mathbf{x}$ & $\mathrm{x}$ & low saline, shallow water \\
\hline Elphidium Subarcticum & & & $\mathbf{x}$ & & $\mathrm{x}$ & low saline, shallow water \\
\hline Elphidium oregonense & & & $\mathbf{x}$ & & & low saline, shallow water \\
\hline Eoponidelza pulchelza & & & & $\mathbf{x}$ & $\mathrm{x}$ & low saline, lagoonal \\
\hline Epistominelia takayanagii & & & & $x$ & & bathyal zone, shelf edge \\
\hline Eponides tenera & & & & & & sandy, nearshore - abyssal \\
\hline Eponides sp. & & $\mathbf{x}$ & & & & sandy, nearshore - abyssal \\
\hline Eissurina marginata & $\mathbf{x}$ & & $\mathbf{x}$ & $\mathbf{x}$ & $x$ & bathyal - outer shelf \\
\hline Glabrateiza wrightii & $\mathrm{x}$ & & & $\mathrm{x}$ & $\mathrm{x}$ & ancient, nearshore \\
\hline Globigerina quinqueloba & & $x$ & & & & cold water, marine nearshore \\
\hline Islandielza istandica & $x$ & $\mathrm{x}$ & $x$ & $x$ & $x$ & low saline, shallow water \\
\hline Islandielza norcrossi & & & $\mathrm{x}$ & $\mathrm{x}$ & $\mathbf{x}$ & low saline, shallow water \\
\hline Islandiella Teretis & & $\mathrm{x}$ & & & & low saline, shallow water \\
\hline Lagema striata & & $\mathrm{x}$ & & & & clay, nearshore - abyssal \\
\hline Neogloboquadrina pachyderma & & $\mathbf{x}$ & & $\mathrm{x}$ & $\mathrm{x}$ & $\operatorname{arctic}$ \\
\hline Nonionelio auriculata & & $\mathbf{x}$ & $\mathrm{x}$ & $x$ & & sandy, nearshore - bathyal \\
\hline oolina borealis & $\mathrm{x}$ & & $\mathrm{x}$ & & $\mathrm{x}$ & temperate, nearshore - bathyal \\
\hline Protelphidium orbiculare & $\mathrm{x}$ & $\mathrm{x}$ & $\mathrm{x}$ & $\mathrm{x}$ & $\mathbf{x}$ & low saline \\
\hline Rosalina sp. & & & & $\mathrm{x}$ & & sandy coastal \\
\hline Trifarina fluens & & & $\mathrm{x}$ & $\mathrm{x}$ & $\mathrm{x}$ & nearshore - bathyal \\
\hline $\begin{array}{l}\text { Virgulina fusiformis } \\
\text { Virgulina schreibersiana }\end{array}$ & & $\mathrm{x}$ & & $\begin{array}{l}x \\
x\end{array}$ & $\mathrm{x}$ & $\begin{array}{l}\text { nearshore - abyssal } \\
\text { nearshore - abyssal }\end{array}$ \\
\hline virguizna schrezdersiand & & & & $x$ & & nearshore - abyssal \\
\hline
\end{tabular}

*Additional information on paleoenvironments after Galloway (1933). 


\section{RAISED BENCHES, TERRACES AND MARINE OVERLAP}

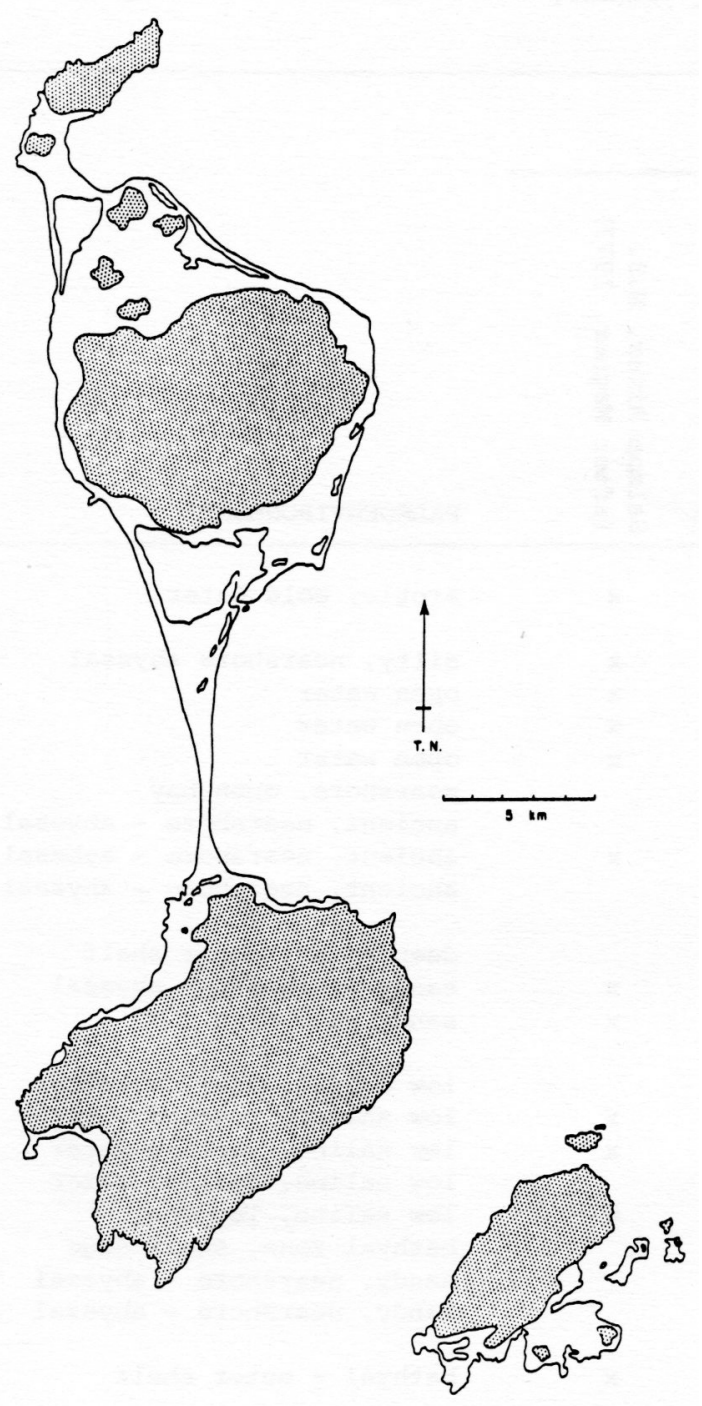

FIG. 3 Mid-Wisconsinian submergence.

Langlade is thought to be a coarsening upward, regressive sequence of shallow water marine to nearshore and subaerial silts, sands and gravels. One would hope, with closer study, to find that the marine unit is underlain by a grey-pink, silty, sandy "Fortune Bay Event" till described in Tucker and McCann (in press). This would complete a sequence similar to that exposed along the lower, southwestern coast of the Burin Peninsula, and extend the range of deposits back to the early wisconsinan. No detailed analyses were attempted on Miquelon, but it is thought that all deposits below $20 \mathrm{~m}$ have been reworked by marine action to some extent. This conclusion is based on cursory examination of coastal material near Grande Anse du Ouest (M7005).
There is ample morphological evidence of marine overlap, despite the contrary findings of Aubert de la Rue. At locations such as le Cap, Miquelon, and near Petit Barachois, bench remnants are visible at 2.4 and $2.6 \mathrm{~m}$. These have been assigned to the $4 \pm 1 \mathrm{~m}$ Sangamonian set visible around the perimeter of the Burin Peninsula because they are striated and capped by surficial material.

Approximately 20 to $25 \mathrm{~m}$ of submergence is recorded around $\mathrm{St}$. Plerre, Langlade and Miquelon (Fig. 3). It is shown by a distinct break in slope between an upland of till, vegetated rock and deeply incised streams, and a lowland of subdued terrain. The lowland is capped by marine sands and gravels, and aeolian material. Because the break in slope occurs at approximately the same height above sea level as the $20 \mathrm{~m}$ a.s.l. collapsed stack at Jacques Fontaine and other raised marine features located farther south on the Burin Peninsula of Newfoundland (Tucker 1979), it is thought to represent the relatively stable and long-term marine stand occurring during the mid-Wisconsinan.

A $9.6 \mathrm{~m}$ a.s.l. raised spit at le Cap, Miquelon, along with similar, raised marine bars on the northern coast of the island of Miquelon, and a $6.4 \mathrm{~m}$ a.s.1. marine terrace at Anse du Gouvernement (Fig. 4), are thought to be late-Wisconsinan in age because of their northward tilt and general agreement with the pattern of post-glacial emergence derived for the Burin Peninsula.

\section{DISCUSSION}

These observations on the Quaternary of the French archipelago lead to several conclusions not previously documented. Most important is that it appears that all of Langlade, most of Miquelon, and the highland of St. Pierre were not glaciated during the late-Wisconsinan. This is suggested by the distinct lack of till at the Petit Barachois section of Langlade, the presence of Salmon River, Nova Scotia correlative forams at the same location, and the general absence of ice stagnation features in the uplands. The southwest, onshore directed striae, cutting earlier striae resulting from mainland, Newfoundland ice, along with southwesterly oriented morainal remnants, eskers and meltwater channels, imply that the last ice to affect the southern coastal portion of St. Pierre and the west coast of Miquelon was the same that influenced the lower Burin Peninsula during the late, midWisconsinan (Tucker and McCann, in press). It is not clear if the Burin Peninsula ice was continuous with that in the Miquelon highlands. It may be that limited patches of ice existed beyond a well defined terminus in a manner similar to that described for the late-Wisconsin limit near Terrenceville and swift Current at the head of the Burin Peninsula. Certainly, the greater than $275 \mathrm{~m}$ deep channel between Miquelon and the Burin Peninsula (Canadian Hydrographic Service 1970) would deem this situation plausible because it is unlikely that so limited a cap would have been able to cross such a barrier. Although stratigraphic work on Langlade is incomplete, and only loosely correlated by way of the formintfera with that on the southwest Burin Peninsula, it is considered precise enough to place more accurately the dispersal centre of 


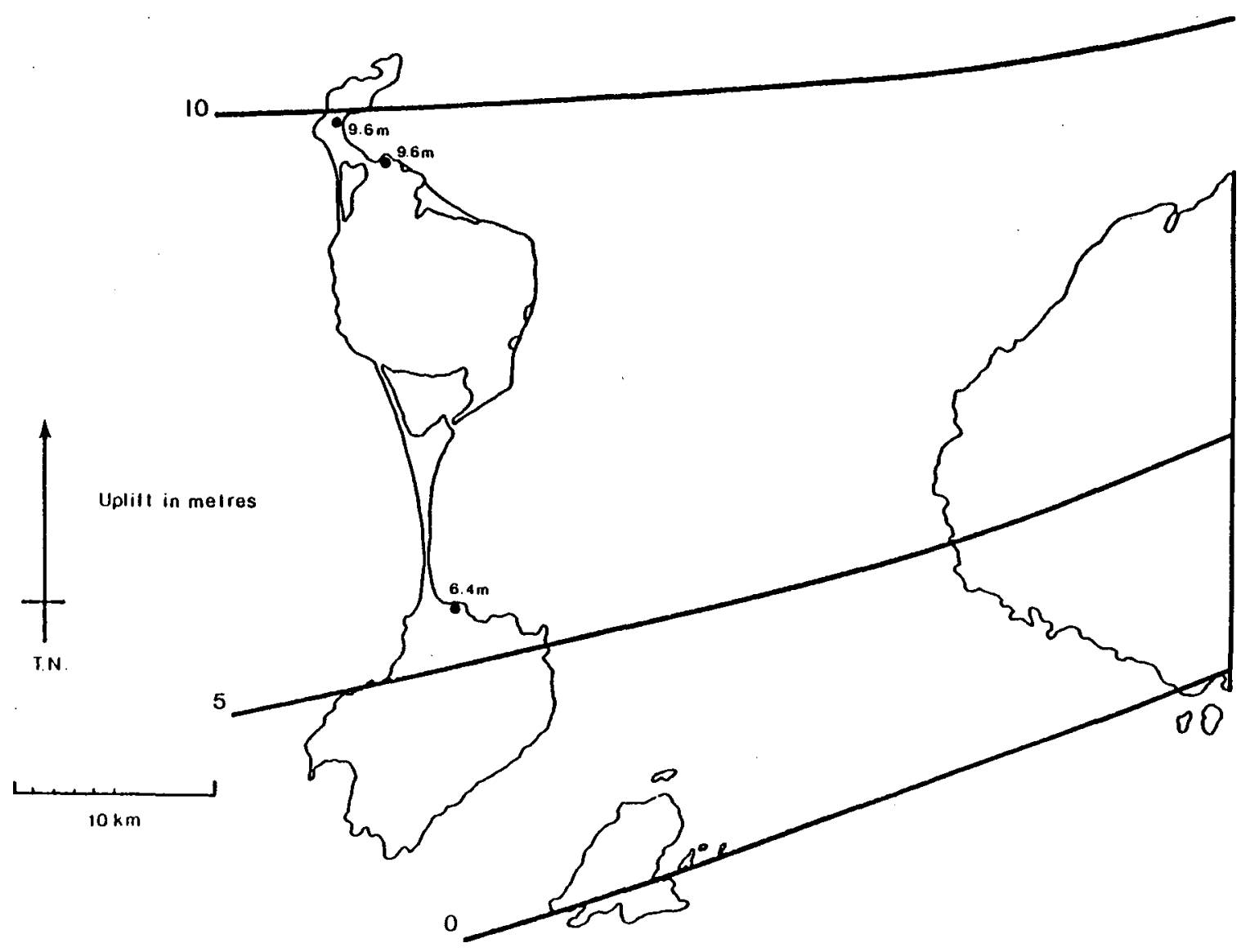

FIG. 4 Isopleths of posiglacial emergence.

the late mid-Wisconsinan ice to the southeast, but west of the $250 \mathrm{~m}$ channel which cuts the centre of Placentia Bay (Canadian Hydrographic Service 1970). Three periods of marine overlap are thought to have occurred: one during the Sangamonian, which cut the marine bench at approximately $2.6 \mathrm{~m}$; one during the mid-Wisconsinan, from which about 20 $m$ of overlap is recorded over unconsolidated deposits; and a final, lower, late-Wisconsinan. overlap on the northern tip of Langlade and around the coast of Miquelon. The southern portions of Langlade and St. Pierre are considered to be submergent in a manner similar to the southeast coast of the Burin Peninsula.

\section{ACKNOWLEDGEMENTS}

The author is indebted to G. Vilks of the Atlantic Geoscience Centre of the Geological Survey of Canada for his identification of, and comments on the foraminifera in the marine sands and silts at Petit Barachois and Dantzic Cove. However, the responsibility for correlating these units with the Salmon River section in Nova Scotia rests with the writer. The research was funded by National Research Council of Canada operating grant $\mathrm{A} 5082$ and the Canadian Department of Energy, Mines and Resources Research Agreement No. 2239-4-154-77 held by S.B. McCann, McMaster University.

\section{REFERENCE $S$}

Aubert de la Rüe, E. 1932. Premiers résultats d'une mission géologique aux îles SaintPierre et Miquelon. Revue de Géographie physique et Géologie dynanique, Paris, 5(4), pp. 417-456.

Aubert de la Rüe, E. 1946. Sur la presence de pseudo-concrétions argilosableuses dans la moraine du Petit Barachois (archipel de Saint-Pierre et Miquelon). Bulletin Societe Géologique Francais, 5e serie, 16, pp. 169-172.

Aubert de la Rüe, E. 1951. Recherches Géologiques et Miniéres aux iles Saint-Pierre et Miquelon. Office de la Recherche Scientifique OutreMer, Ministére de la France d'Outre-Mer. Paris, pp. 75.

Canadian Hydrographic Service 1970. Bathymetric Chart: Newfoundland Shelf No. 802. Canadian Hydrographic Service Marine Sciences Branch, Department of Energy, Mines and Resources, Ottawa.

Galloway, J.J. 1933. A manual of Foraminifera. Principia Press, Bloomington, Indiana, pp. 483.

Grant, D.R. 1977. Glacial style and ice limites, the Quaternary stratigraphic record, and changes of land and ocean level in the Atlantic Provinces, Canada. Géographie Physique et Quaternaire, 31, pp. 247-260. 
Nielsen, E. 1974. A mid-Wisconsin glacio-marine deposit from Nova Scotia. (Abstract). In Quaternary Environments. Ed. W.C. Mahaney, Geographical Monographs No. 5, York Univ., Atkinson College, Toronto. pp. 59-60.

Pettijohn, F.J. 1975. Sedimentary Rocks. Harper and Row, New York, pp. 464-466.

Tarr, W.A. 1935. Concretions in the champlain Formation of the Connecticut Valley. Geological Society of America, Bulletin, 46, pp. 14931534 .

Tucker, C.M. 1979. Late Quaternary Events on the Burin Peninsula, Newfoundland. Ph.D. Thesis, McMaster University, pp. 282.
Tucker, C.M. and McCann, S.B. Quaternary events on the Burin Peninsula, Newfoundland and the islands of St. Pierre and Miquelon, France. Canadian Journal of Earth Sciences (in press).

Williams, H. 1971. Geology, Burgeo (east half), Newfoundland. Geological Survey of Canada Map 1280A.

Williams, H. 1978. Tectonic lithofacies map of the Appalachian Orogen. Memorial University of Newfoundland Map No. 1.

Wagner, F.J.E. 1977. Palaeoecology of marine Pleistocene Mollusca, Nova Scotia. Canadian Journal of Earth Sciences, 13, pp. 661-667. 